Article

\title{
Historic Urban Landscape Approach and Port Cities Regeneration: Naples between Identity and Outlook
}

\author{
Fortuna De Rosa * and Maria Di Palma * \\ Department of Architecture, University of Naples “Federico II” (Italy), Via Roma 402, \\ Napoli 80134, Italy \\ * Authors to whom correspondence should be addressed; E-Mails: fortuna.derosa@unina.it (F.D.R.); \\ maria.dipalma@unina.it (M.D.P.); Tel.: +39-081-25-38847; Fax: +39-081-25-38649.
}

Received: 2 September 2013 / Accepted: 23 September 2013 / Published: 30 September 2013

\begin{abstract}
The aim of this paper is to highlight some perspectives for the sustainable development of Naples, to direct future policies for the city. The proposed approach is based on the Historic Urban Landscape, which, being structurally integrated/systemic, allows the relationship between the historic center and the waterfront, as well as many contradictions, to be overcome, which in the city of Naples, have become particularly acute. The notion of Historic Urban Landscape (HUL) is the latest contribution to the international debate concerning the identification, preservation and valorization of cultural heritage. This new category, in fact, refers to the notion of context to emphasize the systemic interrelation between economic, social, environmental and cultural factors and the complexity of the framework within which conservation policies are inserted. It is in this perspective that the experiences of planning taking place in Naples are read, as a starting point for an innovative approach to the issue of an integrated conservation of the Historic Urban Landscape and, more generally, of the regeneration of the city. The starting point is the study of the experiences of urban transformation in some European port cities in order to "learn from comparison" to develop a theoretic approach based on the understanding of reality. The comparative analysis of case studies, through the synthesis of the most significant aspects of each port city, allows the relationship that exists between a phenomenon and its context to be understood and the critical success factors to be identified, in order to transfer the knowledge gained from good practices in the processes of regeneration of the city of Naples. Naples, for its stratified urban fabric, rich in tangible and intangible cultural values, and for its particular nodal position within the Mediterranean basin, lends itself effectively to a different approach to urban regeneration, which focuses on the relationship between the historic city and the sea.
\end{abstract}


Keywords: Historic Urban Landscape; port cities; best practices; sustainable development; creativity

\section{Introduction}

The challenges we face today, particularly in a context characterized by turbulence and instability, are related to three orders of change:

- demographic changes (population growth, urbanization);

- structural changes (globalization, growth of trade and relations, economic growth in emerging countries);

- environmental changes (climate change, pollution, degradation of natural resources).

These changes and related challenges are evident in port cities, as they are characterized by a particular complexity. In fact, the phenomenon of urbanization is concentrated along the coasts, and of all growing cities, coastal cities are those with the highest levels of vulnerability (risk of hurricanes, tsunamis, floods and other environmental disasters).

This paper's purpose is to demonstrate that one has to start from the city, from local and from port cities, in particular, to overcome the state of crisis we are experiencing and transform these challenges into opportunities: it is here that the urban question becomes strongly interrelated with environmental, economic and social development [1].

A port city is an ideal observation point for understanding the dynamics of ongoing urban transformation and for charting new paths of development in contemporary cities.

The increasing attention to interventions along coastlines and the phenomenon of regeneration/redevelopment of the waterfront have opened new perspectives in the debate on urban development.

With a wide series of experiments, the port city has thus become the laboratory for experimentation and innovation, where recovery of improved urban quality is a key objective in successful cases.

In particular, the historic waterfront can be considered the most fruitful creative place in the city, when the renewed relationship between the center and the port becomes an opportunity to combine the demands of urban conservation with those of competing in the global network.

In this context, we intend to analyze and interpret some of the most significant transformative experiences of the historic port city, in order to identify significant elements to be transferred in the process of the regeneration of Naples, where the innovative and cultural potential of a city and, in particular, cultural heritage is not only an asset rooted in the history of a place, but a driving force for the future development of cities [2].

The key to understanding the experiences of urban regeneration is given by the category of Historic Urban Landscape, which allows one to highlight the most successful transformations, derive from the recognition of the complexity of the urban system and, recovering the historical relationship between city and port, enable sustainable interventions on a territory in which the changing needs and demand for conservation reach a new equilibrium of mutual support and real interaction. 
In this perspective, the "water resource" not only has an instrumental and economic value for transporting goods and people, but becomes a key component of the urban landscape [3].

Attention is thus turned to the experiences of the historic port city, whose waterfront redevelopment is not only limited to producing examples of quality architectural design, but is able to trigger wider processes of urban renewal, in which the reconstruction of the relationship between the old town and port areas has assumed a strategic role in the regeneration of the entire city, by seeking a balance between the different dimensions.

The rapid growth of cities has changed the role and aspect of historic urban centers. New functions were assigned to historical settlements, particularly in the service sector and tourism, which contributed to the welfare of the community, but often, also, to uncontrolled development and improper use of heritage assets, causing a progressive loss of material and non-material value [4].

Global processes have had a profound impact on the integrity of urban areas and the perception of the environment and the values associated with them, as in the lives of their inhabitants and users. Increasing urbanization has offered economic, social and cultural opportunities, which can improve the quality of the urban environment, but also formed, over time, a threat to the spirit of the place, the identity of the community and the integrity of the urban fabric.

The notion of Historic Urban Landscape [5] is the latest contribution to the international debate concerning the identification, preservation and valorization of cultural heritage. The Historic Urban Landscape approach considers the urban area as a historical stratification of natural and cultural values, and includes a wider historical urban context, as well as its geographical environment.

The new perspective of Historic Urban Landscape (HUL) defines a complex framework of reference in which new conservation policies are included:

- from conservation of monuments and archaeological sites to management of living cities and cultural landscapes (the context as a systemic interrelation between economic, social, environmental and cultural factors);

- from mono-disciplinary processes of restoration and urban regeneration, to an integrative and participatory process of the management of change;

- from preservation of buildings to enhancement of value, integrating the aims of urban conservation and socio-economic development.

The new vision related to the concept of Historic Urban Landscape is aimed at preserving the quality of the human environment and at improving the productivity of urban spaces, integrating the objectives of conservation of urban heritage with socio-economic development, on the basis of a balanced and sustainable relation between the built and the natural environment.

The approach centered on the historic urban landscape is inspired by the tradition of local communities of promoting respect for their values, recognizing the importance of historic areas and the values related to their history and collective memory in modern societies [6].

The UNESCO (United Nations Educational, Scientific and Cultural Organization) recommendations reflect the considerable changes that the theory and practice of urban heritage conservation have known in recent decades and identify a number of specific threats that hinder the preservation of historical territories, establishing general principles, policies and guidelines to face the new opportunities and challenges more effectively. The new policies to preserve urban heritage should 
be integrated into a wider urban context, so that sustainable development of these areas is based on the forms and practices of historical tradition. These policies should provide mechanisms to reconcile the conservation and sustainable management of long-term and short-term goals. A coherent approach, in which conservation is an integral part of urban planning, should also explore technical solutions and innovative planning methods applicable to the historic environment.

The sites protected by UNESCO for the exceptional and uniqueness value of global significance that they enclose provide the clearest example of how the integrated conservation of heritage, based on the Historic Urban Landscape approach, represents a great added value, the most important resource on which to base sustainable development of these territories, through adequate management of specific local conditions. The future of these sites will depend on their ability to be resilient to change, to make sustainable their changes in competition in the global economy, creatively reinventing their role in terms of the relationship between nature's economy (ecology) and man's economy and the relationship between the spirit of places and technology.

\section{The Current Model of the Development of Port Areas}

\subsection{The Unsustainability of the Development of Port Areas}

In Italy, many contaminated sites declared as being of national interest (NIS) are in coastal areas. Examples are the industrial areas of the Taranto Ilva steel plant (the largest in Europe), with 12,859 employees, which is responsible for $92 \%$ of Italian dioxin emissions (source: National Emissions Inventory) [7], Porto Marghera - an area of high industrial concentration (petrochemical, steel, chemical industries) identified as being at risk of environmental pollution, due to industrial effluents in the Venetian lagoon-Manfredonia-its chemical plant is nicknamed the "Seveso of the South", because of the various incidents that have occurred since 1971 - and Priolo/Augusta/Melilli-in the 1950s, one of the largest European petrochemical industries was built here; in the following ten years, the income per capita increased by $12 \%$ in the Syracuse area, but the area is now known as the "triangle of death". The above are just some examples of urban "linear" metabolism in which the environment is instrumentally used to extract resources and to dump waste products. It must, however, pass from this utilitarian view of production to a system that is based on circular processes and that, thanks to reuse/recycling/saving/renewal and recovery/restoration/regeneration, promotes a new urban economic base. However, to base the new urban model only on ecological economics is not enough: we must complement it with additional circuits of value creation, one of which is given by the economics of knowledge and culture [8].

The culture-led urban development strategy is not only based on ecological circularization, but integrates the conservation of cultural heritage with the production of a new culture creation of "creative synthesis" between the elements of tradition, continuity over time, identity and elements of innovation and production of new content and new paths of development, thereby making the city more resilient to change.

A third economy is the relational one; it plays a key role by maintaining ecological economics and culture [9]. 
From these considerations we analyze below some experiences of the waterfront transformation of port cities.

\subsection{Some Experiences of "Waterfront Renaissance"}

The crisis of the port city and the growing separation between downtown and port areas has its roots in the industrial revolution, when the city and the harbor became separate worlds, governed by independent logics. This process of separation is accentuated by the technological innovations that occurred in shipbuilding/logistics and the relocation of many commercial ports and, therefore, the availability of free areas near the sea and the city center $[10,11]$.

These profound transformations are the basis of the "waterfront renaissance" phenomenon, which began in North America in the 1950s, spread to Canada in the 1970s and, later, as a "codified model" will affect many European and Asian cities.

The regeneration of Port Vell in Barcelona is a paradigmatic case of a successful intervention of both physical and economic integration of the port with the city. The key elements of this success can be found in the structure of the development plan based on the opening of the historic port to the city center by improving waterfront accessibility with a system of public spaces, the introduction of recreational function and leisure in Ciutat Vella, the creation of new activities in the port without changing its character, preserving buildings of historical and architectural interest and using a strategy based on the promotion of cultural identity [12]. The key elements that underpin the "Barcelona case" can, therefore, be sought in the innovative strategic plan and organizational structure based on public-private partnership. The "Barcelona model", unfortunately, has been replicated in many cities around the world without keeping in mind the specificities of place and the particular circumstances of action, forgetting that they are the real strengths of any successful urban regeneration.

Therefore, the approach centered on the relationship between the port and the center becomes an opportunity for success in an increasingly diffuse standardized urban and architectural language and to preserve the wealth of values that express local identities.

The challenge is, therefore, finding a balance between regeneration, understood as urban and economic development, and the protection and enhancement of local identity.

The city of Valencia, like Barcelona, has been able to benefit from the hosting of international events, not only to promote its image, but also to provide for implementation and fresh impetus to the processes of urban regeneration already underway since the late 1980s and intended for the redevelopment of the waterfront as an opportunity to recover the relationship between the port area and the city center.

The first interventions of the 1980s on the old dock, with the recovery of historic buildings of particular importance (Tinglados at the harbor and the Watch building) and the redevelopment of the inner harbor as a public space, represented the beginning of a process of port transformation that found fulfilment in the work carried out for the America's Cup in 2007. Positive aspects of the implementation of the interventions related to the sporting event are to be found in the time constraint (the work should have been completed in 2007), which restricted the concentration of efforts to only three years, and in the specific functional requirements and security, as well as aesthetics dictated by the competition, which had to submit the changes of the dock. The interventions were a major 
opportunity for the regeneration of the urban areas, not just of the port, especially since the planned activities had not only been designed on the basis of the sporting event, but as a provisioning service for the city. The reconfirmation of Valencia as the site of the America's Cup in 2010 and the agreement to host the Formula 1 Grand Prix in the inner harbor up to 2015 testify to the success of the development process that was enabled. However, Valencia is a special case, because it has been able to integrate the development of tourism, using the resonance of international events, with the preservation of its cultural heritage in an integrated vision.

Marseille is another port city with a culture-led development strategy. Its ambitious project, Euroméditerranée, created to combat the economic crisis and high unemployment rates, starts from the redevelopment of core urban areas and proposes a model city as a nodal center of Mediterranean culture and, at the same time, a bridge between cultures. Its strategic vision fluctuates, therefore, between cultural exchange in the Mediterranean and the economic dimension of international trade. In the initial phase of the redevelopment project, the proposed model focuses on the quality of cultural and social integration. This focus is on the priority objectives of the cultural institutions, whose programs are developed around issues concerning the Mediterranean, and activities on topics of local and regional relevance. According to this perspective, some projects are born in the waterfront area, such as the MuCEM (Museum of Civilization in Europe and the Mediterranean) and the CRM (Regional Center for the Mediterranean). The restoration of the 19th century buildings in the Docklands since 1991 and the assignment for tertiary activities determines the paths of the area's development toward the service economy.

In the initial stage, the project represented an interesting opportunity to experiment with new forms of regional cooperation among several involved institutions; then, the competition within the region prevailed over the function of territorial balance, creating instability and renegotiation of the initial strategies. In many cases, this has resulted in a lack of expectations generated by the social vision, evident, for example, in the prevailing of real estate interventions in service of profit logic, in the need for public/open space or in the expulsion of immigrants from retrained areas as a result of the increase in property values. Moreover, the initial strategy of proposing Marseille as a cosmopolitan city is moving towards a cultural offer that mostly attracts an international audience, often resulting in a standardized urban landscape to serve globalized needs/preferences. In this regard, the designation of Marseille as the European Capital of Culture for 2013 could be an opportunity to avoid the risk of a city controlled by the model of globalized consumption and to re-establish a trajectory of development that generates the urban landscape as an expression of real social plurality and cosmopolitanism.

After this discussion of some best practices of historical waterfront redevelopment, we want to mention the experience of Liverpool, a city that has transformed local resources into opportunities, triggering the culture-led regeneration processes that enabled it to overcome a phase of economic decline to compete internationally [13].

Liverpool has combined the preservation of cultural heritage with the revival of the economy by investing in sectors, such as maritime transport (the port is among the first in Europe for container handling) and industry, creating one of the largest industrial districts in Europe.

The inclusion of Liverpool in the list of UNESCO World Heritage sites and its designation as European Capital of Culture are two of the events that triggered the processes of urban regeneration, in which the strategic vision of the city is part of a wider redevelopment at the regional level. 
Private financing of the several regeneration initiatives afoot often take over public financing, making operations more economically sustainable, but sometimes projecting toward real estate logic. From this point of view, the identification of a World Heritage Site and the trial of the management plan play roles in the protection and enhancement of historic and complex values associated with it $[14,15]$.

\section{Case Study: Naples between Local Identity and Global Cultural Exchanges}

Naples is the third largest city of Italy and the principal city of southern Italy, capital of the Campania region. Its province has over three million inhabitants over an area of $1171 \mathrm{~km}^{2}$.

The port of Naples is one of the most important in Italy in terms of freight and passengers and is becoming the most important for cruise ship traffic. The revenues generated from tourism and cultural activities are an essential part of economic growth [16].

The port of Naples has considerable importance in the Mediterranean basin, confirmed by the positive trend that commercial traffic has recorded in recent years. Its strategic position between Europe and Asia renders itself an ideal transit area for goods (port cargo-gross weight of goods handled, 21,923,377 t [17], container volume handled, 5,883,494 t, in the year 2010) [18]. The commercial area has a good level of intermodal connections as served by connections to the highways and railways. Passenger traffic between those of the port of Naples is a fundamental activity, considering that it amounts (including cruise passengers, passengers for the islands of the gulf and those related to coastal navigation) to over nine million units. Cruise traffic has achieved excellent results: passengers in 2009 rose to 1,300,000 compared to 1,150,000 in 2008 [19,20].

Moreover, in 1995, the historic center of Naples was inscribed in the UNESCO World Heritage List (World Heritage UNESCO, 1021 ha; UNESCO Buffer Zone ,1350 ha), according to criteria II (Naples is one of the most ancient cities in Europe, whose contemporary urban fabric preserves the elements of its long and eventful history) and IV (its street pattern, its wealth of historic buildings from many periods and its setting in the Bay of Naples give it an outstanding universal value without parallel and one that has had a profound influence in many parts of Europe and beyond), which emphasize the relationship between the city and the sea and the great importance that Naples has always had among the countries of the Mediterranean basin (Figure 1a,b) [21].

However, it is a paradox that, although the relationship with the sea is one of the main features of the UNESCO Historic Centre of Naples, the waterfront itself is always present as a physically separate entity from the city. On the coast of Naples, three urban areas are recognizable as morphologically different, all poorly connected to the urban fabric: the central-eastern area from Vigliena to Molosiglio, where all the industrial and port activities always take place, which has established itself as a historical barrier between the city and the sea; the central area from Molosiglio to Posillipo, the most relevant landscapes in which the city faces the sea with the system of the promenade; and the western area, which corresponds to the industrial area of Bagnoli, which from the beginning of 1900, has intervened as a historical barrier between the city and the sea and the adjacent Gulf of Pozzuoli.

In the local planning instruments, in particular, the City Plan in 1972 and the last one in 2004, this issue remained unresolved: the two documents did not show any planning strategy from which we can infer a real desire to recover this relationship. 
Figure 1. (a) Naples: UNESCO historic center. (b) Naples: World Heritage Site and buffer zone.

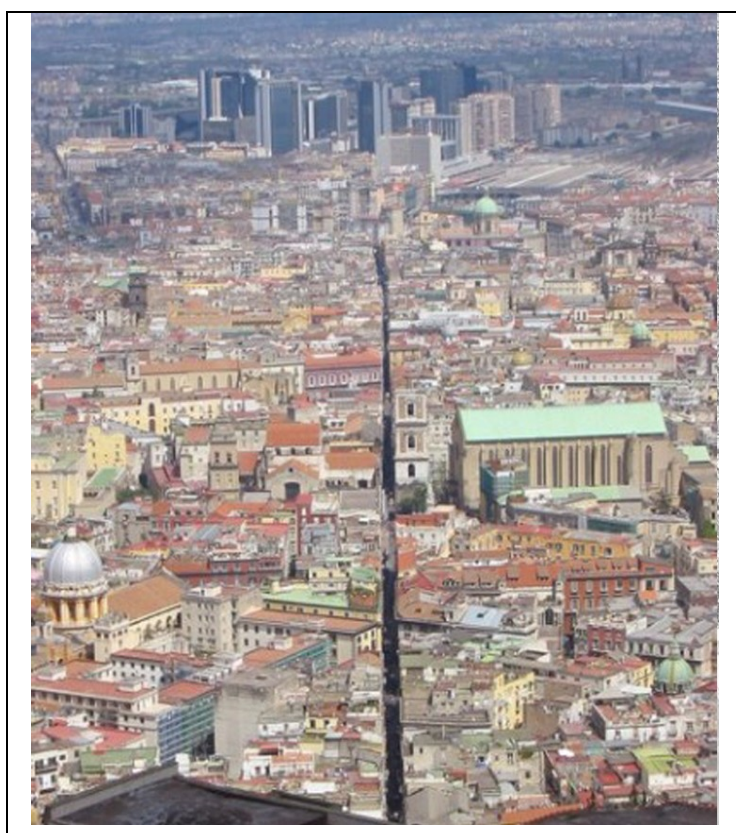

(a)

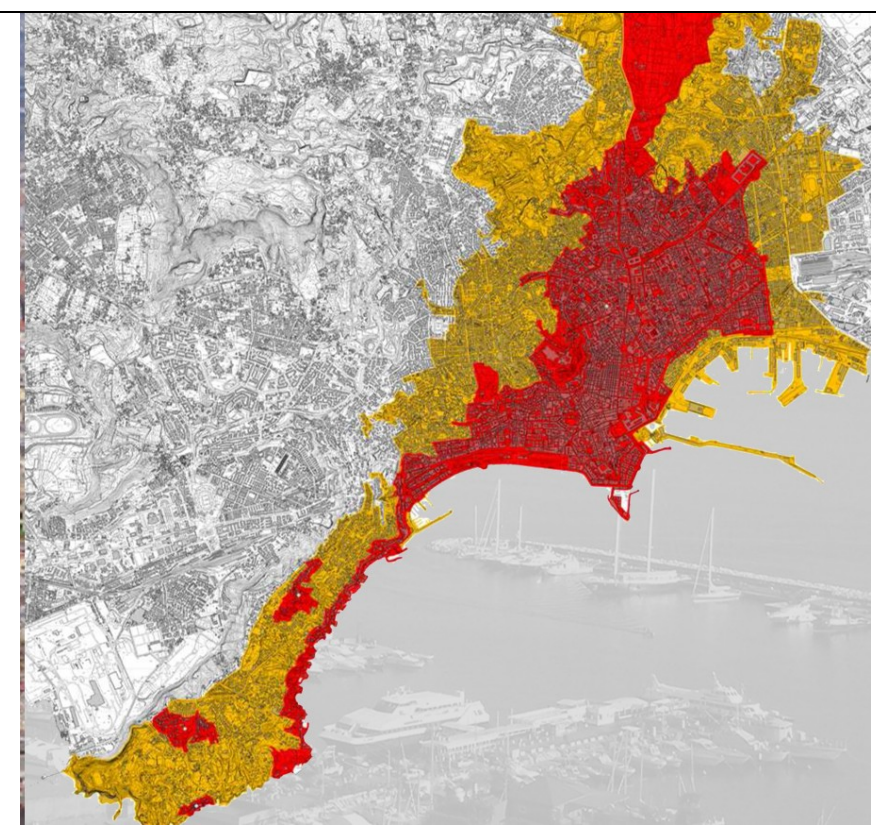

(b)

Source: Management Plan of the historic center [21].

Nor has significant progress been made with the recent management plan prepared for the UNESCO World Heritage Site (February 2011). It is one of the first management plans to introduce the Historic Urban Landscape (HUL) concept as an instrument for reflecting on criteria and methods of conservation and enhancement of the historic center. This tool serves as the strategic vision of "Napoli Fuoco del Mediterraneo" (Naples Focus of the Mediterranean Sea), which puts the city at the center of the wider system of five UNESCO sites on a regional scale and its port as a fulcrum and point of access to the entire system. In this perspective, the city administration has formulated a proposal for redefining a buffer zone to protect the inscribed property that ensued from a complex reflection in light of the principles of the HUL experimental approach. In this landscape, the "sea" is an additional buffer that protects the integrity of the site, evoking the millenary relationship with nature and the landscape, trade and cultural exchanges. However, although the Management Plan (MP.) for the historic center of Naples is considered a "prototype" for the approach to city conservation based on the HUL principle, it has, in fact, several shortcomings, mainly because:

- there is no practical integration of planning tools, such as an MP, for the historic center and the New Port Plan, as a result of the enlargement of the buffer zones of the UNESCO site to the entire port area;

- there is no building of a shared vision and objectives of the plan, based on common values, defined through the active participation of all the forces of civil society.

The New Port Plan considers the area that stretches from La Pietra on the west side to Pietrarsa on the east side. The peculiarity of the port of Naples is that it is one of the few ports in the world not to be sold or transferred to business sectors in other areas or regional towns, and for this reason, the Port 
Plan is designed as a "flexible" tool in relation to the use of port areas, confirming the multifunctionality of the port of Naples as a resource. Starting from this important premise, the Port Plan has been written in terms of time as a period of no more than 10-15 years, and it identifies, as the strengths of the transformation program, Molo San Vincenzo on the west side and Nuova Darsena di Levante on the east side of the waterfront, the so-called "wings" of the port. The two sites, located at the end parts of the port, are the ones in which the most consistent and significant transformations are concentrated and from which modifying, streamlining and organizing spaces and functions of the entire harbor should be started. Focusing on the "wings" means strengthening the two areas on which depends the future development of container and cruise traffic: the strengths of the city economy.

However, the need to recover the relationship between the port area and the historic center of the city, through an integrated and shared strategy, through bottom-up processes, is the innovative approach of recent planning experiences in Naples. It is explicit in the proposal, as formulated in the Territorial Cooperation Program URBACT II 2007-2013, to experiment with new forms of cooperation and agreement on priority issues to reconnect the city and the port, through a feasibility study specifically named the Local Action Plan (LAP). The thematic networks that joined the city of Naples within the URBACT II program are twofold: CTUR-Cruise Traffic and Urban Regeneration - of city port heritage, in which the city of Naples is involved in leading, and HerO-Heritage as Opportunity — in which the city participates as a partner [22,23]. The Local Action Plan is focused on the area of the city named "Città Bassa" and its main objective is: "The waterfront of the historical center and port area from Piazza Municipio to Piazza Mercato: a sustainable development through the improvement of cruise tourism impact"; with three main actions: requalification of the waterfront monumental area and beside the historic urban area, giving new functions to the city and port heritage for urban regeneration, maximizing the economic and social impacts of cruises and supporting the social and economic development of the "lower city" quarter.

The area covered by the Local Action Plans (LAPs) [24] of the thematic networks, CTUR and HerO, consists of that portion of the lower quarters ("Città Bassa") of the city of Naples (Figure 2), which is the "bridge" to the sea. Despite having previously had a strong commercial connotation, this area currently suffers from a situation of abandonment and progressive degradation. Successful initiatives implemented by individuals (i.e., the Consortium Antico Borgo Orefici) with the support of the Municipality of Naples have shown that it is possible to redevelop the area to obtain, at the same time, a positive impact both in the social field (creation of businesses incubators, revitalizing the environment, etc.) and the economic field (increasing the commercial appeal of the site, creating new specialized jobs, etc.). However, the URBACT program does not directly finance individual actions, but the process leading to the identification of the same, and inserts them into a program of intent that the city acquires with a view toward the next project. The LAP is a kind of "road map", a concrete feasibility study, which helps to identify a set of useful solutions to solve problems in an integrated way. The Local Action Plan also identifies potential funding sources that point to various programs at the European and regional level. 
Figure 2. Naples: the Local Action Plan of the lower quarters (“Città Bassa”).

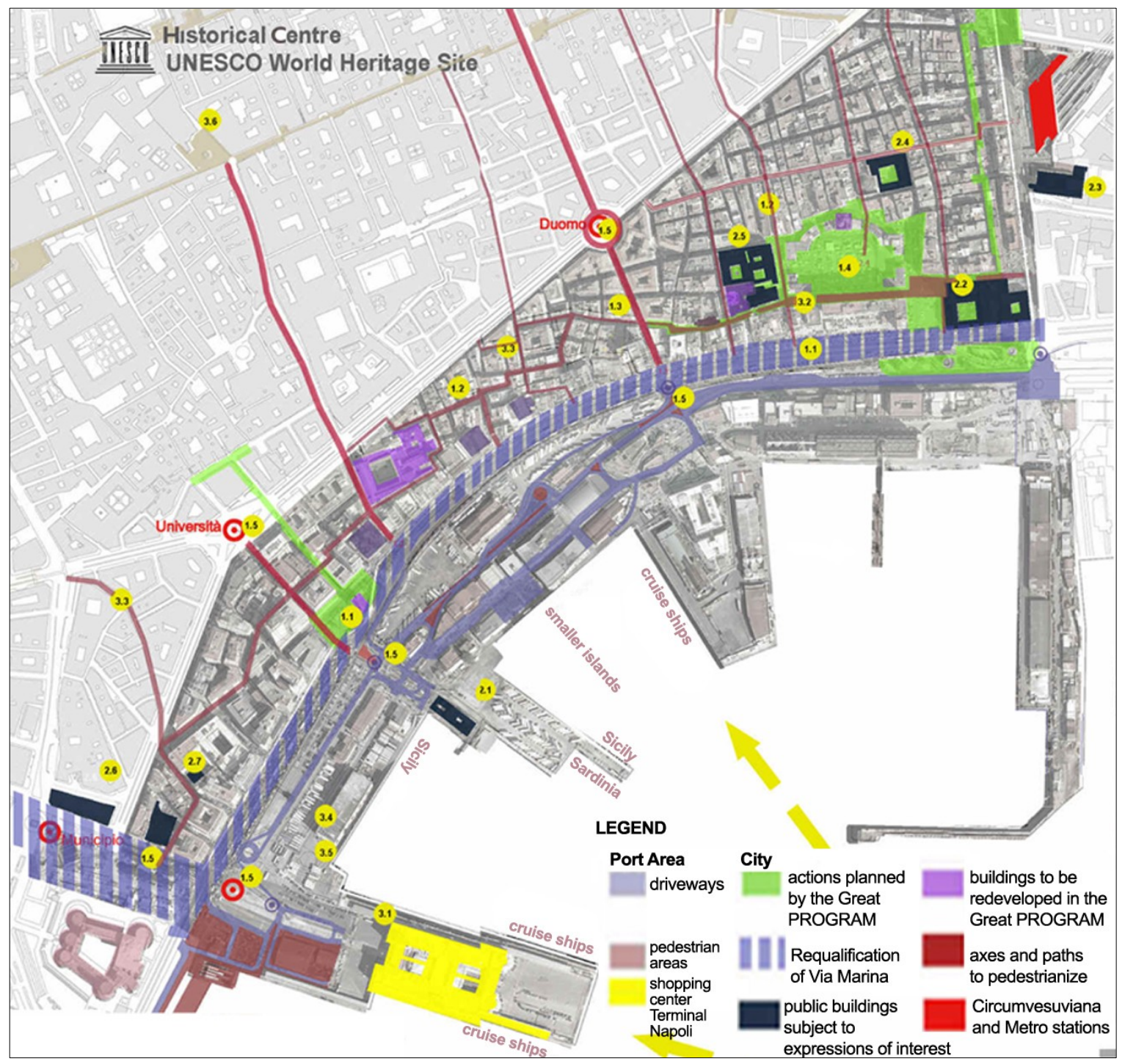

Source: City of Naples. Urbact Local Action Plans [24].

The different actors involved in the URBACT Local Support Group, as well as relating to one another, agree to follow the entire process from concept to realization. The Local Support Group (URBACT Local Support Group-ULSG) consists of representatives of stakeholders at various levels - authorities, local and non-citizens, individuals, associations, universities and any stakeholders which can make a contribution to the design and implementation of the Local Action Plan (Figure 3). All the stakeholders in the first phase can contribute to the construction of the Local Action Plan, proposing possible actions to take on the area of "Città Bassa", identified as an area of intervention for the thematic networks, CTUR and HerO.

The urban regeneration of the quarters of the so-called "Città Bassa", which is the area that extends from Piazza Municipio to Piazza Mercato, and the establishment of local support groups, i.e., public and private subjects participating actively in the process of identifying individual actions, are the two main objectives for the start-up phases of the project. 
Figure 3. Naples: URBACT Local Support Group.

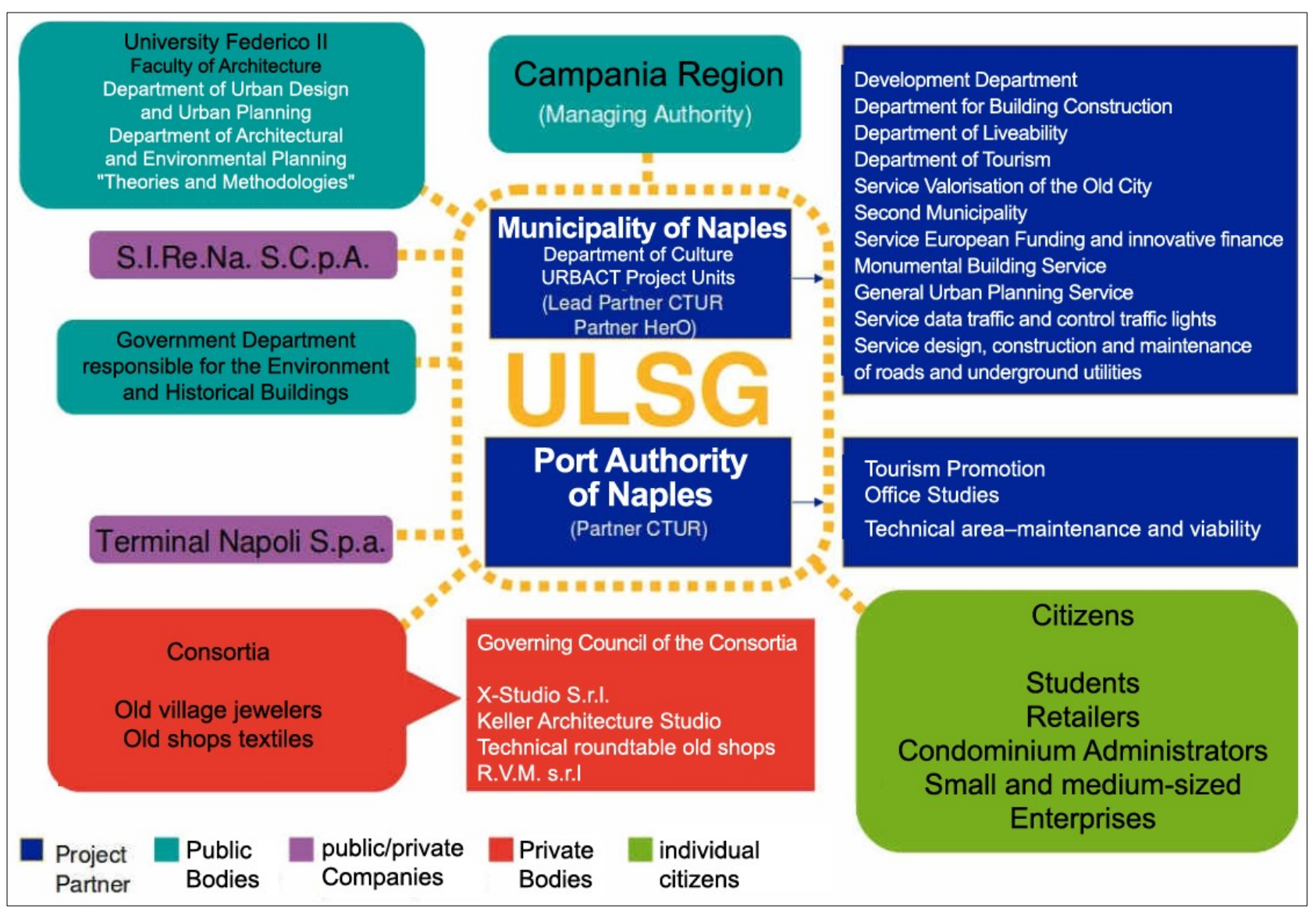

Source: City of Naples. Urbact Local Action Plans. [24].

The LAP proposes, in general, the rationalization and networking of interventions/initiatives/ideas, both public and private, of the target zone, pointing to the regeneration of the urban fabric - part of the UNESCO historic center - and the increase in the flow of tourism, with particular attention on cruise traffic, which is constantly increasing. The LAP focuses on the physical reconnection between two urban fabrics: that of the historic city and that of the so-called "Città Bassa", through redevelopment, proposing, at the same time, to create the conditions to improve the livability of the area for residents and to increase job opportunities arising from the tourism revival and the subsequent resumption of commercial and artisan quality activities that characterize it. The attempt is to rebuild the relationship between the port and the historic center through the "Città Bassa", identifying pedestrian paths, restoring some of the many buildings of historical and cultural interest, stimulating activity related to culture and entertainment, redeveloping the urban voids, creating activities related to trade and crafts, improving information systems, roads and the public transport system, etc.

In this way, the "Città Bassa" could become a viable alternative to normal pathways of penetration into the historic center and be a real showcase for the craft and commercial activities of the city and a real attraction, given its proximity to the harbor and the Maritime Station, for cruise tourism, which could have important economic repercussions for the district and, in general, for the city of Naples.

The Local Action Plan, of course, responds to the priorities of the administration and is consistent with the actions already taken or to be taken in the area of interest, such as the Great Program for the 
Old Town UNESCO World Heritage Site, the Strategic Orientation Document (DOS), the Preliminary Program of the Integrated Urban (PIU) and the Management Plan of the UNESCO site of the city of Naples.

\section{Benchmarking between Naples and European Port Cities}

The study of the experiences of urban transformation in some European port cities and the "Naples case" is designed in order to "learn from comparison" [25] to develop a theoretic approach based on the understanding of reality.

The comparative analysis of case studies, through the synthesis of the most significant aspects of each case study, allows the relationship that exists between a phenomenon and its context to be understood $[25,26]$ and the critical success factors to be identified.

From a vision of sustainable urban development, 16 indicators of "urban sustainability" were defined (Table 1), representing economic, cultural, environmental and social aspects, and the relative level of performance of the different case studies [27].

Table 1. Dimensions of sustainability and related indicators.

\begin{tabular}{|c|c|}
\hline Dimensions & Indicators \\
\hline \multirow{4}{*}{ Environment } & $\mathrm{CO}_{2}$ emissions $(\mathrm{t})$ \\
\hline & Recovery/recycling/regeneration of waste materials (\%) \\
\hline & Green spaces (\% urban surface) \\
\hline & National/international awards for virtuous policies (number) \\
\hline \multirow{4}{*}{ Society } & Employment ratio (\%) \\
\hline & 6. Ethnicity $(\%)$ \\
\hline & Crime (n) \\
\hline & Festivities/celebrations in the year (n) \\
\hline \multirow{4}{*}{ Economy } & 9. $\quad$ Active businesses count $(\mathrm{n})$ \\
\hline & 10. Tourist port flows (passengers number) \\
\hline & 11. Port cargo - gross weight of goods handled ( $\mathrm{t})$ \\
\hline & 12. Funds for the protection/enhancement of cultural heritage (euro) \\
\hline \multirow{4}{*}{ Culture } & 13. Universities/research centers (n) \\
\hline & 14. Cultural organizations $(n)$ \\
\hline & 15. Cultural (national/international) events (n) \\
\hline & 16. UNESCO area (ha) \\
\hline
\end{tabular}

Source: Authors.

For each case examined, it was thus possible to delineate its "sustainability profile" [25] through the verification of the results achieved for each of the four dimensions of sustainability.

The values of the indicators were appropriately expressed by a rating scale capable of making explicit the relative level of performance $(0=$ null; $1=$ very low; $2=$ low; $3=$ average; $4=$ high; 5 = very high) (Table 2) [28-31].

In this way, it was possible to structure a matrix that permits comparison of the profiles of the four cities that were objects of the study (Table 3). 
Table 2. Matrix of performances.

\begin{tabular}{llcccc}
\hline \multicolumn{1}{c}{ Indicators } & Naples & Valencia & Marseille & Liverpool \\
\hline 1. & $\mathrm{CO}_{2}$ emissions & 5 & 3 & 4 & 5 \\
2. & Recovery/recycling/regeneration of waste materials & 1 & 3 & 5 & 2 \\
3. & Green spaces & 1 & 1 & 1 & 5 \\
4. & National/international awards for virtuous policies & 0 & 5 & 5 & 3 \\
5. & Employment ratio & 2 & 5 & 4 & 2 \\
6. & Ethnicity & 1 & 5 & 3 & 4 \\
7. & Crime & 2 & 2 & 5 & 4 \\
8. & Festivities/celebrations in the year & 5 & 4 & 2 & 2 \\
9. & Active businesses count & 4 & 4 & 4 & 5 \\
10. & Tourist port flows & 5 & 1 & 2 & 1 \\
11. & Port cargo-gross weight of goods handled & 1 & 3 & 5 & 2 \\
12. & Funds for the protection/enhancement of cultural heritage & 2 & 1 & 5 & 1 \\
13. & Universities/research centers & 3 & 5 & 2 & 3 \\
14. & Cultural organizations & 4 & 2 & 3 & 5 \\
15. & Cultural (national/international) events & 5 & 3 & 3 & 4 \\
16. & UNESCO area & 5 & 1 & 0 & 1 \\
\hline
\end{tabular}

Source: Authors.

Table 3. Frequency analysis of performances.

\begin{tabular}{ccccccc}
\hline \multirow{2}{*}{ Cities } & \multicolumn{7}{c}{ Frequency of scores } \\
\cline { 2 - 7 } & $\mathbf{0}$ & $\mathbf{1}$ & $\mathbf{2}$ & $\mathbf{3}$ & $\mathbf{4}$ & $\mathbf{5}$ \\
\hline Naples & 1 & 4 & 3 & 1 & 2 & 5 \\
Valencia & 0 & 4 & 2 & 4 & 2 & 4 \\
Marseille & 1 & 1 & 3 & 3 & 3 & 5 \\
Liverpool & 0 & 3 & 4 & 2 & 3 & 4 \\
\hline
\end{tabular}

Source: Authors.

For a comprehensive description of the results of the analysis of the case studies and a direct comparison between the levels of performance of the different cities, "spider diagrams" have been used (Figure 4) [32,33], in which, defined on appropriate scale values, the four different experiences are represented by complex shapes.

The frequency analysis of the scores of the performances for the different indicators of the four cities shows that:

- Naples tends to have performances with opposite values (very high or very low). The lowest scores (0-1) are those relating to ecological indicators, while the highest scores (4-5) are achieved in the cultural indicators;

- Valencia achieves very high values for social indicators (4-5) and arrives at the highest score (5) in four cases, while for all other remaining indicators, the scores are medium-low;

- Marseille has the best performance in the economic and environmental indicators; it reaches the maximum score (5) two times out of four each, while lower and middle values (3-2) are attained for the cultural and social indicators; 
- Liverpool is the city that achieves the lowest performance in the economic indicators (1-2), attaining higher values (4-5) only in the cultural indicators.

The systematization of data through appropriate indicators is useful for recognizing the interrelationship between the various aspects of sustainability and the consequent need for a multidimensional approach in defining the choices for sustainable urban development. This type of evaluation allows the main components that can affect, in a significant way, the building of sustainable future choices to be explained [34-36].

Figure 4. Comparative analysis between Naples and European port cities.

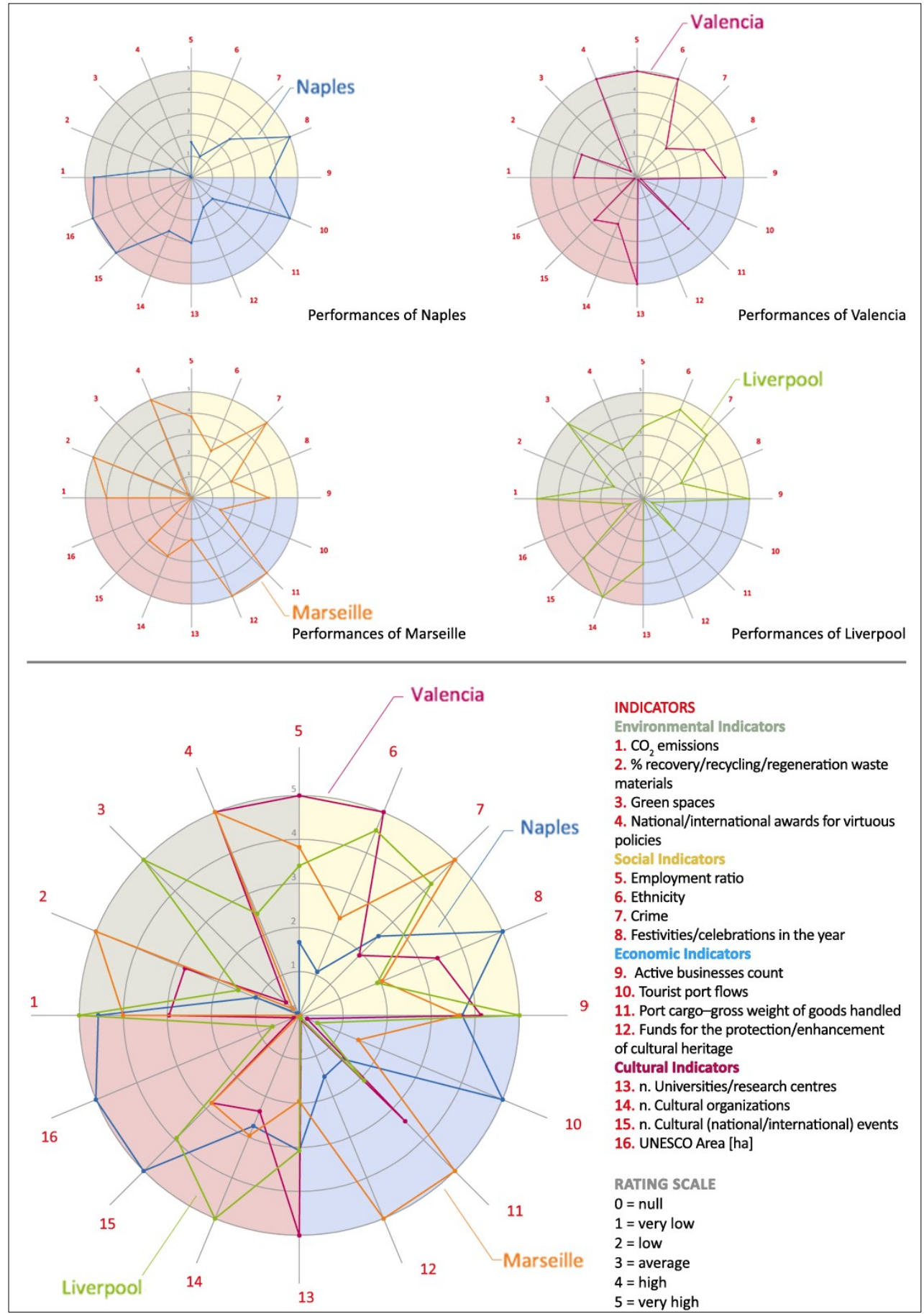

Source: Authors. 


\section{Conclusions and Outlook}

Port cities have always been nodes and magnets of trade flows for goods and people.

The current crisis has highlighted the limitations and negative externalities of a development model based exclusively on trade, in which the port becomes a logistics machine separated from the city. The crisis, therefore, represents an opportunity for the transition to a new model of urban development, where the economy is no longer based only on trade, but also on the exchange of knowledge [37].

The redevelopment projects described above demonstrate that the model of successful urban development to overcome the crisis is based on culture. Several port cities have invested in their cultural resources to exit from the post-industrial decline and recover the relations between port and city, but in order for these interventions to be truly effective and allow wider processes of urban and sustainable regeneration to be triggered, it is necessary for the culture/knowledge economics to be made circular [4].

The analysis of the different urban dimensions of Naples and the comparison with those of other cities allows the deficiencies in the current management of the city to be identified and provides a clear direction on how to guide policy development with fundamental respect to the principles of sustainability.

As evidenced by the cultural indicators considered, Naples has a significant UNESCO area (1021 ha-buffer zone, 1350 ha) [14], much larger than those of other analyzed cities. Moreover, even the significant presence of universities, specialized research centers and cultural associations and last, but not least, the number of cultural events at the national/international level that take place during a year place it in a competitive position.

The positive trend of cultural components is further supported by social issues related to the strong sense of belonging, of rootedness to places and cultural traditions, as highlighted by the social indicator on the number of public holidays and annual ceremonies, which is well above average compared to other cities.

However, these components are not sufficient to trigger processes of urban development. In fact, by comparison with the European experience, the city of Naples shows that, compared to the rich presence of cultural resources related both to the built heritage and to social capital, there is a poor ability to enhance the same. Moreover, attention to the environmental component is much lower than in the other cities. Despite the critical situation that is common to all the major European metropolises, the analyzed cities have responded to the increasing environmental impacts of economic activities through appropriate strategies for conservation and enhancement of the environment. The presence of awards for the activation of virtuous policies represents a significant indicator. A positive example is the city of Valencia, which has reconciled the growth of the flows of handled goods from its port with an environmental management system, becoming the first commercial port to obtain EMAS (Eco-Management and Audit Scheme) certification in Spain [38].

In the case of Naples, a lack of integration between the policies of the port and urban areas is also found when comparing the data of the flow of goods and port tourism (Naples reaches high levels of about 7-8 million passengers per year) [39] with employment rates that are much lower than other cities. Therefore, there is no correspondence between the great liveliness of industries linked to the port sector and the labor market. 
The foregoing shows that the success of the process of urban transformation depends on the ability to produce not only added income, but also social and human capital, and this is closely tied to the way interventions are managed and the intensity of the relationships activated.

The context pushes cities to rival each other to survive, to promote their image to attract tourists, to use the city brand to position itself on the global market with the risk of focusing only on the "spectacle" of the city, as sometimes happens in the case of mega-events that are not managed with a sustainable approach.

So that the culture-based model does not become just the excitement of the urban image and the self-celebration of its cultural heritage, it is necessary that urban development projects are anchored to the local context in order to prevent the homologation of globalization and that they are capable of fostering relationships/synergies, both within individual cities through public-private-community partnerships and between cities through the creation of cooperative networks that can enhance mutual exchange according to a "co-evolutionary" approach [40,41].

The proposed model of local development is based on a relational economy with three circuits of value creation: ecological, cultural and social. In this strategic model, the third sector (social enterprises, foundations, non-profit organizations) carries out a relevant role: the civil economy supports a cultural and green economy and builds relationships $[42,43]$.

The third sector recognizes the centrality of intrinsic compared to instrumental values; it assumes a time horizon of the medium-long term and produces circular processes in the exchange.

From this perspective, the notion of relations and the notion of the common good (landscape, cultural heritage, environment) assume a relevant role.

The Historic Urban Landscape approach of the UNESCO Management Plan and URBACT initiatives, CTUR and HerO, shows how sustainable development of the city of Naples necessarily passes through the recovery of the relationship between the port area and the UNESCO historic center (Figure 5).

Figure 5. Naples: port area and UNESCO historic center.

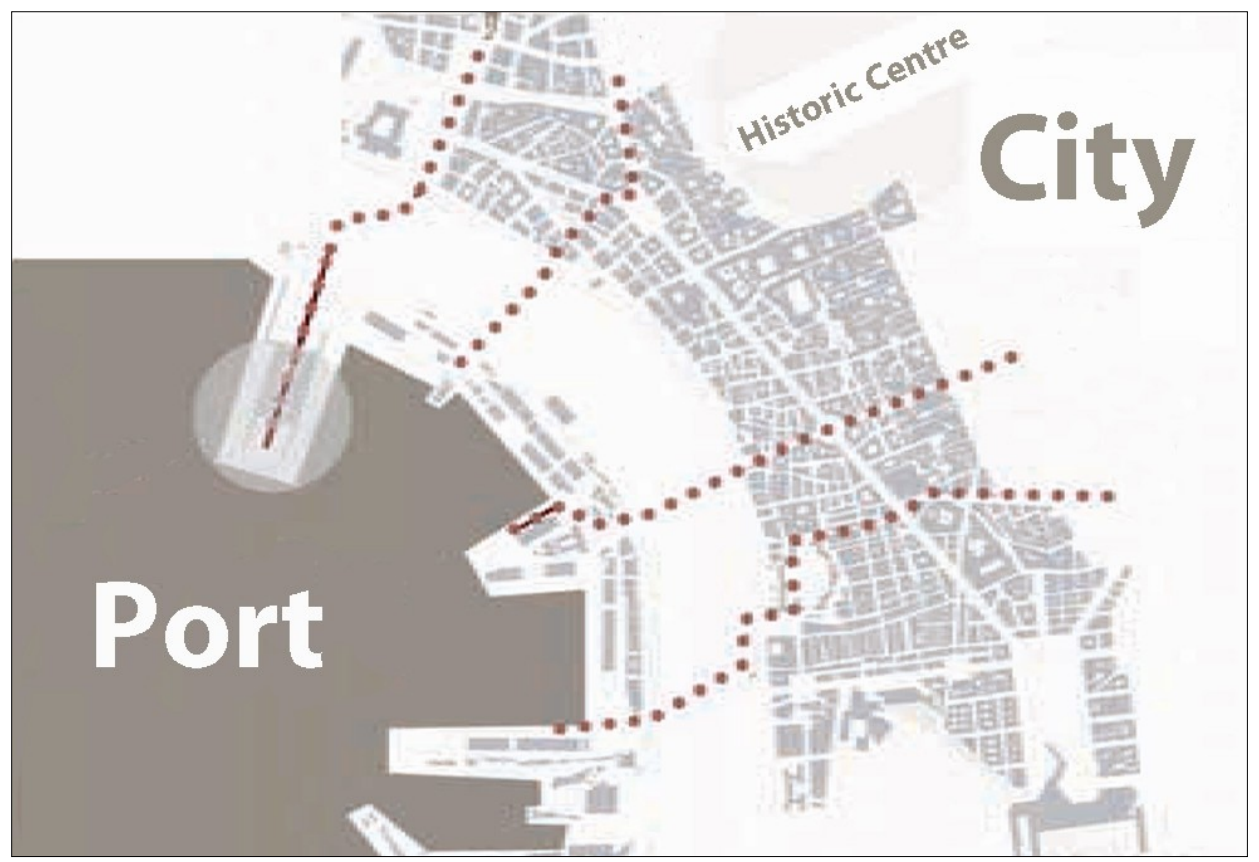

Source: Authors. 
The municipal planning instrument in force suffers from a complete lack of attention to the need for the City of Naples to reconstruct the ancient relationship with the sea, which has long been lost. The actions proposed in the lower quarters by the current City Plan are limited to the issue of mobility, the implementation of the plan for parking areas and the connection between the monumental complex areas and big public works for access to the city center, highlighting the need for connection mainly between marginal areas of the city and the most central areas, completely excluding the possibility of upgrading the connection with the coastal area. Moreover, the guiding principle of the plan seems to suffer from an extremely conservative attitude that tends to embalm the historic city and to deny any possible intervention of a transformation that combines conservation and innovation, old and new. Furthermore, the port area also suffers from the lack of normed rules in the Port Plan, which is waiting for approval and subsequent implementation. In addition, this tool does not provide the necessary relocation of the commercial activities from port areas to more suitable areas, nor more delineated specialization and destinations for them. Naples is one of the few port cities in the world where a variety of functions coexist: from passenger cabotage, to shipbuilding and commercial activity into its components of freight, oil and container [44].

In what way can urban connections and, therefore, social ones be ensured between areas whose identity matrix is difficult to identify and historical areas that need a radical renewal? The urban form of the city comes from the historical needs of the citizens, but at the same time, cannot be conceived without an urban interconnection project with port areas and without homogenization between the different planning tools in both the local and wider area.

Naples is a city inscribed in the World Heritage List (WHL) UNESCO for its unique urban and architectural heritage.

The governance improvement, namely, a systematization between the institutions, the academic and the business world, is an important and necessary ingredient to consider tradition and innovation as critical factors for the success of a winning strategy for territorial development. The experiences of CTUR and HerO are, therefore, only a first, although significant, step towards a different methodological approach to city planning, which must necessarily base its sustainable development strategies on the recovery of the relationship between the port area and the historic center [45-47].

The analysis of the best practices described above shows that port areas can constitute the entry point and core place for sustainable development for the entire urban system. It is the starting point on which to build future strategies for the regeneration of the city of Naples.

The Historic Urban Landscape approach can become a real perspective through integrated conservation (Amsterdam Charter, 1975-Washington Charter, 1987) [48,49], which considers new relationships within the management plan/program:

- Conservation and development

- Ancient and new values

- Old technologies and new technologies

- Tangible capital and intangible capital

- Man-made capital and natural capital

- Economic values and ecological values

- Economic values and ethical values

- Wealth production and wealth distribution

- Private interests and public/general interest 
According to the Historic Urban Landscape approach, the management plan/program assumes a central role as a tool for implementing new and innovative multidimensional instruments.

In particular, the management plan/program for urban sustainable development of Naples should be a tool to:

- Reduce conflicts of public and private involved interests to acceptable levels;

- Improve institutional organization, creating a favorable environment for stakeholder coordination;

- Stimulate inhabitants' participation to public choices regarding common goods;

- Spread the "culture of relationality", because cultural heritage bridges ancient and new, particular and general, permanence and change...;

- Cultivate creativity and innovation [50];

- Improve city resilience [51].

\section{Conflicts of Interest}

The authors declare no conflict of interest.

\section{References}

1. Schubert, D. Transformation Processes on Waterfronts in Seaport Cities. In Port Cities as Areas of Transition, 1st ed.; Waltraud, K., Ed.; Transcript Verlag: Bielefeld, Germany, 2008.

2. Lazrak, F.; Nijkamp, P.; Rietveld, P.; Rouwendal, J. Cultural Heritage and Creative Cities: An Economic Evaluation Perspective. In Sustainable City and Creativity: Promoting Creative Urban Initiatives; Fusco Girard, L., Nijkamp, P., Baycan, T., Eds.; Ashgate: London, UK, 2012; pp. 225-243.

3. Schubert, D. Seaport Cities: Phases of Spatial Restructuring and Types and Dimensions of Redevelopment. In Port Cities: Dynamic Landscapes and Global Networks, 1st ed.; Hein, C., Ed.; Routledge: London, UK, New York, NY, USA, 2011; pp. 54-69.

4. Schubert, D. Ever-Changing Waterfronts: Urban Development and Transformation Processes in Ports and Waterfront Zones in Singapore, Hong Kong and Shanghai. In Port Cities in Asia and Europe Transformations, 1st ed.; Graf, A., Chua Beng, H., Eds.; Routledge: London, UK, New York, NY, USA, 2009.

5. UNESCO. Recommendation on the Historic Urban Landscape; UNESCO World Heritage Centre: Paris, France, 2011.

6. Perchinunno, P.; Rotondo, F.; Torre, C.M. The evidence of links between landscape and economy in a rural park. Int. J. Agric. Environ. Inf. Syst. 2012, 3, 72-85.

7. National Emissions Inventory. Available online: http://www.epa.gov/ttn/chief/eiinformation.html (accessed on 23 October 2012).

8. Fusco Girard, L. Sustainability, creativity, resilience: Toward new development strategies of port areas through evaluation processes. Int. J. Sustain. Dev. 2010, 13, 161-184.

9. Selicato, M.; Torre, C.M.; La Trofa, G. Prospect of integrate monitoring: A multidimensional approach. Lect. Notes Comput. Sci. 2012, 7334, 144-156.

10. Hoyle, B.S.; Pinder, D.A. European Port Cities in Transition; Belhaven Press: London, UK, 1992.

11. Hoyle, B.S.; Pinder, D.A.; Husain, M.S. Port Areas and Urban Transformations; Mursia: Venezia, Italy, 1997. 
12. Lambiri, D. The Olympic Village of Barcelona: Urban Residential Development and Socioeconomic Impact. In International Research on Sports Economics and Production; Papanikos, G.T., Ed.; Athens Institute of Education and Research: Athens, Greece, 2005; 195-210.

13. Goodman, L. Managing Mersey Waterfront. Portus 2007, 13, 16-21.

14. Garcia, B.; Melville, R.; Cox, T. Creating an Impact: Liverpool's Experience as European Capital of Culture; University of Liverpool: Liverpool, UK, 2010.

15. Collett, M.; Campbell, P.; Cox, T. Liverpool's Creative Industries. Understanding the Impact of the Liverpool ECoC on the City Region's Creative Industries; University of Liverpool: Liverpool, UK, 2009.

16. Comune di Napoli. Available online: http://www.comune.napoli.it (accessed on 24 October 2012).

17. Federazione del mare. IV Report on the Economy of the Sea; Franco Angeli: Milano, Italy, 2011.

18. Autorità Portuale di Napoli. Available online: http://www.porto.napoli.it/ (accessed on 25 October 2012).

19. Forte, F. Port and Territorial System: The Case of Campania. In Tourist Ports: Multidisciplinary Approach to an Integrated Planning Strategy, 1st ed.; Viola, P., Colombo, E., Eds.; Dario Flaccovio Editore: Palermo, Italy, 2010; pp. 101-134.

20. Forte, F. Port-city areas, looking to the future. BDC 2012, 12, 644-663.

21. Management Plan of the UNESCO site "Historic Centre of Naples". Available online: http://www.comune.napoli.it/flex/cm/pages/ServeBLOB.php/L/IT/IDPagina/14142 (accessed on 26 October 2012).

22. CTUR PROJECT. Available online: http://urbact.eu/en/projects/port-cities/ctur/ (accessed on 24 October 2012).

23. HerO PROJECT. Available online: http://urbact.eu/en/projects/urban-renewal/hero/homepage/ (accessed on 24 October 2012).

24. City of Naples. Urbact Local Action Plans. Available online: http://urbact.eu/fileadmin/Projects/ HERO/projects_media/LAP_Naples.pdf (accessed on 24 October 2012).

25. Fusco Girard, L.; Nijkamp, P. Energy, Beauty, Participation: The Challenge of Sustainability; Franco Angeli: Milano, Italy, 2005.

26. Weick, K.E. The Social Psychology of Organizing; Random House: New York, NY, USA, 1979.

27. Zeleny, M. Autopoiesis and self-sustainability in economic systems. Hum. Syst. Manag. 1997, 16, 251-262.

28. Zeleny, M. Multiple Criteria Decision Making; McGraw-Hill: New York, NY, USA, 1982.

29. Nijkamp, P.; van Delft, A. Multi-Criteria Analysis and Regional Decision-Making; Springer-Verlag: Berlin, Germany, 1977.

30. Nijkamp, P.; Spronk, J. Multiple Criteria Analysis; Gower: Aldershot, UK, 1981.

31. Nijkamp, P.; Rietveld, P.; Voogd, H. Multicriteria Evaluation in Physical Planning; Elsevier Science Publishers: Amsterdam, The Netherlands, 1990.

32. Fusco Girard, L.; Nijkamp, P. Assessments for Sustainable Development of the City and Territory; Franco Angeli: Milano, Italy, 1997.

33. Zeleny, M. In Search of Cognitive Equilibrium: Beauty, Quality and Harmony. In Estimation and Environmental Economics; Fusco Girard, L., Ed.; Franco Angeli: Milano, Italy, 1993.

34. Nijkamp, P. Environmental Policy Analysis; John Wiley: Chichester, UK, 1980. 
35. Nijkamp, P.; van Lierop, F.J. Local Developments and Urban Planning; Springer-Verlag: Berlin, Germany, 1981.

36. Nijkamp, P.; Fischer, M.; Papageorgiou, Y. Spatial Choices and Processes; North-Holland Publishing Company: Amsterdam, The Netherlands, 1991.

37. Fusco Girard, L. The urban future. BDC 2012, 12, 19-34.

38. Kourtit, K.; Nijkamp, P.; Stough, R. Drivers of Innovation, Entrepreneurship and Regional Dynamics; Springer-Verlag: Berlin, Germany, 2011.

39. Fusco Girard, L. Port Areas and Sustainable Development. In Tourist Ports: Multidisciplinary Approach to an Integrated Planning Strategy, 1st ed.; Viola, P., Colombo, E., Eds.; Dario Flaccovio Editore: Palermo, Italy, 2010; pp. 27-45.

40. Alberti, M.; Marzluff, J.M.; Shulenberger, E.; Bradley, G.; Ryan, C.; Zumbrunnen, C. Integrating humans into ecology: Opportunities and challenges for studying urban ecosystems. BioScience 2003, 53, 1169-1179.

41. Holling, C.S. Understanding the complexity of economic, social and ecological systems. Ecosystems 2001, 4, 390-405.

42. Cerreta, M.; Mele, R. A landscape complex value map: Integration among soft values and hard values in a spatial decision support. Lect. Notes Comput. Sci. 2012, 7334, 653-659.

43. Cerreta, M.; de Toro, P. Integrated spatial assessment for a creative decision-making process: A combined methodological approach to strategic environmental assessment. Int. J. Sustain. Dev. 2010, 13, 17-30.

44. Cerreta, M.; de Toro, P. Assessing urban transformations: A SDSS for the master plan of Castel Capuano, Naples. Lect. Notes Comput. Sci. 2012, 7334, 168-180.

45. Fusco Girard, L.; de Toro, P. Integrated spatial assessment: A multicriteria approach to sustainable development of cultural and environmental heritage in San Marco dei Cavoti, Italy. Cent. Eur. J. Oper. Res. 2007, 15, 281-299.

46. Fusco Girard, L.; Torre, C.M. The use of Ahp in a multiactor evaluation for urban development programs: A case study. Lect. Notes Comput. Sci. 2012, 7334, 157-167.

47. Cerreta, M.; Panaro, S.; Cannatella, D. Multidimensional spatial decision-making process: Local shared values in action. Lect. Notes Comput. Sci. 2012, 7334, 54-70.

48. International Council on Monuments and Sites. The Declaration of Amsterdam; Congress on the European Architectural Heritage: Amsterdam, The Netherlands, 1975.

49. International Council on Monuments and Sites. Charter for the Conservation of Historic Towns and Urban Areas (The Washington Charter1987). Available online: http://www.icomos.org/ charters/towns_e.pdf (accsessed on 24 December 2012).

50. Florida, R. The Rise of the Creative Class; Basic Books: New York, NY, USA, 2002.

51. Pickett, S.T.A.; Cadenasso, M.L.; Grove, J.M. Resilient cities: Meaning, models and metaphor for integrating the ecological, socio-economic, and planning realms. Landsc. Urban Plan. 2003, 69, 369-384.

(C) 2013 by the authors; licensee MDPI, Basel, Switzerland. This article is an open access article distributed under the terms and conditions of the Creative Commons Attribution license (http://creativecommons.org/licenses/by/3.0/). 